\title{
METHODOLOGICAL ASPECTS OF TREND STUDIES AND DEVELOPMENT OF THE HBSC STUDY IN THE CZECH REPUBLIC
}

\author{
Erik Sigmund1, Petr Bad'ura1, Dagmar Sigmundová', Ladislav Csémy², Michal Kalman¹ \\ ${ }^{1}$ Institute of Active Lifestyle, Faculty of Physical Culture, Palacký University Olomouc, Czech Republic \\ ${ }^{2}$ Centre of Epidemiological and Clinical Research of Drug Abuse and Dependence, National Institute of Mental Health, Klecany, Czech Republic
}

\section{SUMMARY}

The aim of the study is to present the theoretical background of trend studies in general, to characterize the international Health Behaviour in School-aged Children (HBSC) study and to describe its methodology and changes of the Czech HBSC study between 1994 and 2014. The first part describes various types of trend research studies including their advantages and disadvantages. The second part summarizes the history of the HBSC study in an international context and particularly in the Czech Republic. The final part presents the basic methodological data from six surveys conducted in the Czech Republic between 1994 and 2014.

Key words: trend, longitudinal, secular, HBSC, children, study

Address for correspondence: D. Sigmundová, Faculty of Physical Culture, Palacký University Olomouc, trída Míru 117, 77111 Olomouc, Czech Republic. E-mail: dagmar.sigmundova@upol.cz

https://doi.org/10.21101/cejph.a4953

\section{INTRODUCTION}

\section{Theoretical Background of Trend Studies}

Regardless of the particular research method, the sample is pivotal in every single study. This is because most studies aim to generalize their findings to larger populations $(1,2)$. If the sample comprises the entire population, then the survey is called a 'census' (3). Otherwise, it is optimal to use a representative sample of a given population (4). In developmental research scholars use a cohort, which means a group of individuals who shared the same event (often their birth) during the same time period (usually a year) (4).

Developmental research studies are challenging in terms of the study design. As a result of maturation and ageing, lifespan research studies in particular are influenced by intraindividual changes in participants and variations in the courses of their lives in different historical and cultural contexts (4).

Developmental research includes studies that investigate changes in behaviour over a certain period of time $(4,5)$. There are two basic kinds of such studies - cross-sectional and longitudinal (6). Another kind of study that monitors changes over time is called a 'time-lag study' (7). Ecological studies, which focus on the comparison of groups of people rather than individuals, can also be included in trend studies. All the above-mentioned kinds of studies can be either descriptive or experimental in their nature, though longitudinal studies are often associated with an experiment $(4,8)$.

Longitudinal studies attempt to address a research question concerning history or changes in society $(9,10)$. In general, longitudinal studies can be understood as those that monitor the same persons repeatedly at several points in time (10). Such a study usually monitors groups or individuals, with time serving as an independent variable. The data is collected at periodic time intervals (8). The duration of longitudinal studies is, in principle, several years but there are also some that go on for decades. Studies of this kind contribute significantly to the body of knowledge thanks to the monitoring of the same persons over a longer time period $(6,8,9,11)$. A noteworthy advantage of longitudinal studies is that they capture the changes over time as a continual process (12). This type of research allows a large number of people to be monitored, while the influence of the researcher is minimized (9). However, the length of the research amplifies its difficulty. The main concerns regarding longitudinal studies are represented by their time-consuming character and sample attrition as a result of, for instance, migration, disease, mortality or loss of interest in participation in the research $(6,9)$. Of course, it is possible to recruit new participants. This approach raises several (especially methodological) issues, though $(9,12)$.

Cohort and panel studies are classified as longitudinal as well $(13,14)$. At the beginning of a cohort study, the participants are split into groups depending on the presence or absence of a certain factor (e.g. disease). In its simplest form, a cohort study compares a group exposed to such a factor with another group, which is unexposed. This kind of study can be conducted either as a prospective or a retrospective study or a combination of these. In these studies, participants are usually monitored for a long period of time in order to observe clinical manifestations of disease. Cohort studies are the best way to identify the prevalence and natural progression of disease and are often used in epidemiology research $(14,15)$. 
A panel study is a kind of longitudinal study and monitors the same sample of persons, households, or organizations over time (13). The initiation of panel research is ascribed to Paul Felix Lazarsfeld, who made great strides in this field in the 1930s/40s. Panel research allows rough changes, the causality of processes, and the dynamics of social, cultural, and economic changes over time to be captured. It answers questions such as: Which individuals change? Why does the change happen? The panel data is used to deepen the understanding of the effects of social and economic policies $(13,16)$. One limitation of such studies is that the quality of the data collected may be affected by sample attrition or an improperly determined time period between the individual surveys of the panel research study. This limitation is, however, also found in all other kinds of long-term research $(12,16)$.

Accelerated longitudinal design combines the pros of longitudinal and cross-sectional surveys, while putting the emphasis on maintaining the longitudinal nature of the data (17). It concerns the collection of a limited number of repeated measurements from independent age cohorts, with a time overlap of the data regarding these cohorts $(4,18)$. The basic principle of accelerated longitudinal design lies in the fact that long-term developmental changes can be estimated using significantly shorter periods $(4,17,19)$. A simple example of this design is the replacement of longitudinal monitoring of a cohort from 10 years old up to the age of 15 by several shorter longitudinal surveys, i.e. concurrent monitoring of 10-, 11-, and 12-year olds over a three-year period. The aggregate data on those three cohorts then represents an age interval from 10-15 years. Such a design enables the comparison of cohorts of the same age at different points in time (secular trends) or different cohorts at the same time, as well as the development of particular cohorts $(4,17,19)$.

Another example could be the monitoring of a given variable from 12 to 19 years of age, which can be ensured by two concurrent longitudinal surveys using a cohort of 12- to 15-year-olds and another one of 16- to 19-year-olds (18). A well-considered research design can yield much more relevant information with less effort, compared with traditional longitudinal research (4).

Cross-sectional studies investigate several age groups at the same time. Thus, they are neither as time-consuming nor as costly as longitudinal studies $(6,20)$. Cross-sectional studies are of a descriptive nature. In these studies, analyses of variables in participant groups are performed at the same time and associations among variables are assessed $(8,20)$.

The limitation of cross-sectional studies is called a 'cohort issue' (6). The absence of a time dimension (as opposed to longitudinal studies) hinders the interpretation of the findings (10). In general, the cohort issue may be defined as follows: Do all the age groups that are investigated indeed come from the same population? For instance, is the difference observed in physical activity between 14-year-old and 10-year-old children caused by increasing age? Or did the level of physical activity of the 10-year-old cohort differ from those aged 14 when they were 10 years old? As it is impossible to answer such questions when possessing only crosssectional data, conclusions regarding causal pathways between the variables being investigated cannot be drawn. Moreover, the results of cross-sectional studies are prone to selection bias (6). The results of cross-sectional studies might erroneously report on changes in a given variable depending on the respondents' age, while it might in fact be caused by differences between cohorts. Longitudinal studies, on the other hand, might incorrectly observe changes in a given variable as depending on the respondents' age, while actually the changes are rather attributable to the specific or historical period in which the repeated measurements were conducted (4). Cross-sectional studies therefore probably provide evidence of changes attributable to age instead of changes over time (21).

Some of the limitations of cross-sectional research can be eliminated by repeating several waves of a cross-sectional study, which in principle do not investigate the same participants. This is then called a 'time lag' study. Time lag studies compare samples of the same age category in different time periods (22). Such a research design enables the longitudinal processing of data and cross-sectional analyses, as well as a combination thereof. A similar design mixing a cross-cohort comparison and 'follow-up' two to four years after the initial data collection was introduced in a Chinese study of mothers and their children (23). The study compared two different cohorts of children (and their mothers); the follow-up measurement was performed at intervals of 2-4 years. This design allowed the cohorts to be compared and also made it possible to capture the long-term changes in both of them.

The studies observing trends are essential for monitoring the prevalence or development of the variables that are investigated. They serve as an evidence base for other studies or interventions. The monitoring of trends is also used for checking the efficiency of interventions, both during an intervention itself and in the follow-up measurement after its end. As such, these trend studies have an essential role in research and also the transfer of research findings into practice.

\section{Health Behaviours in School-aged Children Study}

The Health Behaviours in School-aged Children (HBSC) study is a cohort cross-sectional questionnaire-based study focusing on health and health-related behaviours in 11-, 13-, and 15-year-old adolescents in the context of their social environment (24). This age was selected because of the significant cognitive, psychological, and biological processes taking place in this period of the lifespan, as well as because of the fact that health-related behaviours adopted in this age are known to persist into adulthood. The findings from the HBSC study are used to monitor health, well-being, and health-related behaviours in school-aged children; deepen the understanding of the social determinants of health; and provide evidence-based data for policy makers and practitioners aiming to improve the lives of young people (25).

The first survey was conducted in 1983/84 in five countries and soon after its establishment the HBSC became recognized as a 'WHO collaborative study' by the WHO Regional Office for Europe. The second one, in 1985/86, took place in 13 countries. Since then the HBSC data has been collected at four-year intervals and the number of member states has gradually risen. Currently, the HBSC research network consists of 45 countries/regions across Europe and North America*.

Membership of the HBSC network is subject to unconditional compliance with the international research protocol (e.g. standardized questionnaire, back-translation of the research items, or

*For a full list of member countries please see www.hbsc.org 
provision of a representative sample), which has been developed by the expert research team. The HBSC questionnaire comprises a standardized mandatory module (which must be introduced in all member countries), standardized optional packages (extending research topics from the mandatory module), and also national items, which can be included independently by national teams. Further details about the HBSC methodology or the standard version of the questionnaire have been reported elsewhere $(26,27)$.
The centralization of research activities through international centres is typical of HBSC. The International Coordinating Centre was established at the Child and Adolescent Health Research Unit at the University of Edinburgh, Scotland. Since 2011 it has been relocated to the University of St. Andrews, Scotland.

Similarly, the data handling within the HBSC is also centrally controlled and the Data Management Centre responsible for the preparation of all member countries' datasets for the HBSC international reports is at the University of Bergen, Norway. This

Table 1. HBSC member states included in the international datasets, 1983-2014

\begin{tabular}{|c|c|c|c|c|c|c|c|c|}
\hline 1983/1984 & $1985 / 1986$ & $1989 / 1990$ & $1993 / 1994$ & $1997 / 1998$ & $2001 / 2002$ & $2005 / 2006$ & $2009 / 2010$ & $2013 / 2014$ \\
\hline $\begin{array}{l}\text { England } \\
\text { Finland } \\
\text { Norway } \\
\text { Austria } \\
\text { Denmark }\end{array}$ & $\begin{array}{l}\text { Finland } \\
\text { Norway } \\
\text { Austria } \\
\text { Denmark } \\
\text { Belgium (Fr) } \\
\text { Hungary } \\
\text { Israel } \\
\text { Scotland } \\
\text { Spain } \\
\text { Sweden } \\
\text { Switzerland } \\
\text { Wales } \\
\text { Netherlands }\end{array}$ & $\begin{array}{l}\text { Finland } \\
\text { Norway } \\
\text { Austria } \\
\text { Denmark } \\
\text { Belgium (Fr) } \\
\text { Hungary } \\
\text { Scotland } \\
\text { Spain } \\
\text { Sweden } \\
\text { Switzerland } \\
\text { Wales } \\
\text { Netherlands } \\
\text { Canada } \\
\text { Latvia } \\
\text { N. Ireland } \\
\text { Poland }\end{array}$ & $\begin{array}{l}\text { Finland } \\
\text { Norway } \\
\text { Austria } \\
\text { Denmark } \\
\text { Belgium (Fr) } \\
\text { Hungary } \\
\text { Israel } \\
\text { Scotland } \\
\text { Spain } \\
\text { Sweden } \\
\text { Switzerland } \\
\text { Wales } \\
\text { Netherlands } \\
\text { Canada } \\
\text { Latvia } \\
\text { N. Ireland } \\
\text { Poland } \\
\text { Belgium (FI) } \\
\text { Czech Rep. } \\
\text { Estonia } \\
\text { France } \\
\text { Germany } \\
\text { Greenland } \\
\text { Lithuania } \\
\text { Russia } \\
\text { Slovakia }\end{array}$ & $\begin{array}{l}\text { England } \\
\text { Finland } \\
\text { Norway } \\
\text { Austria } \\
\text { Denmark } \\
\text { Belgium (Fr) } \\
\text { Hungary } \\
\text { Israel } \\
\text { Scotland } \\
\text { Spain } \\
\text { Sweden } \\
\text { Switzerland } \\
\text { Wales } \\
\\
\text { Canada } \\
\text { Latvia } \\
\text { N. Ireland } \\
\text { Poland } \\
\text { Belgium (FI) } \\
\text { Czech Rep. } \\
\text { Estonia } \\
\text { France } \\
\text { Germany } \\
\text { Greenland } \\
\text { Lithuania } \\
\text { Russia } \\
\text { Slovakia } \\
\text { Greece } \\
\text { Portugal } \\
\text { Ireland } \\
\text { USA }\end{array}$ & $\begin{array}{l}\text { England } \\
\text { Finland } \\
\text { Norway } \\
\text { Austria } \\
\text { Denmark } \\
\text { Belgium (Fr) } \\
\text { Hungary } \\
\text { Israel } \\
\text { Scotland } \\
\text { Spain } \\
\text { Sweden } \\
\text { Switzerland } \\
\text { Wales } \\
\text { Netherlands } \\
\text { Canada } \\
\text { Latvia } \\
\text { Poland } \\
\text { Belgium(FI) } \\
\text { Czech Rep. } \\
\text { Estonia } \\
\text { France } \\
\text { Germany } \\
\text { Greenland } \\
\text { Lithuania } \\
\text { Russia } \\
\text { Slovakia } \\
\text { Greece } \\
\text { Portugal } \\
\text { Ireland } \\
\text { USA } \\
\text { Macedonia } \\
\text { Italy } \\
\text { Croatia } \\
\text { Malta } \\
\text { Slovenia } \\
\text { Ukraine }\end{array}$ & $\begin{array}{l}\text { England } \\
\text { Finland } \\
\text { Norway } \\
\text { Austria } \\
\text { Denmark } \\
\text { Belgium (Fr) } \\
\text { Hungary } \\
\text { Israel } \\
\text { Scotland } \\
\text { Spain } \\
\text { Sweden } \\
\text { Switzerland } \\
\text { Wales } \\
\text { Netherlands } \\
\text { Canada } \\
\text { Latvia } \\
\text { Poland } \\
\text { Belgium (FI) } \\
\text { Czech Rep. } \\
\text { Estonia } \\
\text { France } \\
\text { Germany } \\
\text { Greenland } \\
\text { Lithuania } \\
\text { Russia } \\
\text { Slovakia } \\
\text { Greece } \\
\text { Portugal } \\
\text { Ireland } \\
\text { USA } \\
\text { Macedonia } \\
\text { Italy } \\
\text { Croatia } \\
\text { Malta } \\
\text { Slovenia } \\
\text { Ukraine } \\
\text { Luxembourg } \\
\text { Turkey } \\
\text { Romania } \\
\text { Iceland } \\
\text { Bulgaria }\end{array}$ & $\begin{array}{l}\text { England } \\
\text { Finland } \\
\text { Norway } \\
\text { Austria } \\
\text { Denmark } \\
\text { Belgium (Fr) } \\
\text { Hungary } \\
\text { Israel } \\
\text { Scotland } \\
\text { Spain } \\
\text { Sweden } \\
\text { Switzerland } \\
\text { Wales } \\
\text { Netherlands } \\
\text { Canada } \\
\text { Latvia } \\
\text { Poland } \\
\text { Belgium (FI) } \\
\text { Czech Rep. } \\
\text { Estonia } \\
\text { France } \\
\text { Germany } \\
\text { Greenland } \\
\text { Lithuania } \\
\text { Russia } \\
\text { Slovakia } \\
\text { Greece } \\
\text { Portugal } \\
\text { Ireland } \\
\text { USA } \\
\text { Macedonia } \\
\text { Italy } \\
\text { Croatia } \\
\text { Malta } \\
\text { Slovenia } \\
\text { Ukraine } \\
\text { Luxembourg } \\
\text { Turkey } \\
\text { Romania } \\
\text { Iceland } \\
\text { Armenia }\end{array}$ & $\begin{array}{l}\text { England } \\
\text { Finland } \\
\text { Norway } \\
\text { Austria } \\
\text { Denmark } \\
\text { Belgium (Fr) } \\
\text { Hungary } \\
\text { Israel } \\
\text { Scotland } \\
\text { Spain } \\
\text { Sweden } \\
\text { Switzerland } \\
\text { Wales } \\
\text { Netherlands } \\
\text { Canada } \\
\text { Latvia } \\
\text { Poland } \\
\text { Belgium (Fl) } \\
\text { Czech Rep. } \\
\text { Estonia } \\
\text { France } \\
\text { Germany } \\
\text { Greenland } \\
\text { Lithuania } \\
\text { Russia } \\
\text { Slovakia } \\
\text { Greece } \\
\text { Portugal } \\
\text { Ireland } \\
\text { Macedonia } \\
\text { Italy } \\
\text { Croatia } \\
\text { Malta } \\
\text { Slovenia } \\
\text { Ukraine } \\
\text { Luxembourg } \\
\text { Romania } \\
\text { Iceland } \\
\text { Bulgaria } \\
\text { Armenia } \\
\text { Albania } \\
\text { Moldova }\end{array}$ \\
\hline
\end{tabular}

The first survey in the given country which was included in the international dataset is indicated in italics. The datasets from Belgium are given separately for the Flemish (FI) and French (Fr) regions of the country. The number of countries above does not have to correspond to the actual number of member countries in the HBSC network in a specific year. Within some data collection waves, few of the member countries did not provide national datasets as per internal HBSC requirements and, thus, were not included in the international dataset. Adapted from Inchley J. et al., 2016 (25) 
approach facilitates cross-national comparison and also guarantees a continuum in research, thus enabling analyses of trends in health and health-related behaviours in school-aged children. For trend analyses, the design of repeated cross-sectional studies, i.e. the time lag method, is used.

\section{HBSC Study in the Czech Republic}

The Czech Republic joined the HBSC study in 1993/1994, making the last wave of data collection in 2013/2014 the sixth in a row and enabling trends in national data over a 20 -year period to be analyzed. HBSC uses a standardized questionnaire to collect data on the health and health-related behaviours of school-aged children and the Czech version respects the requirements laid out in the protocol (questionnaire layout, order of questions, translation guidelines, etc.) (27).

The origins of the study in the Czech Republic were coordinated by the National Centre for Health Promotion. In 1994, the questionnaire covered sociological questions and items investigating risk behaviours, physical activity, oral hygiene, eating behaviours, health, psychosocial adjustment, injuries, and the school environment. In total, it consisted of 60 questions. After data collection, the Czech data file was sent to the International Data Management Centre at the University of Bergen as prescribed by the HBSC requirements. There the data was cleaned and the sample randomized with regard to the participants' age and gender, leading to a final sample which used 3,585 children aged 11,13 and 15 years (28). This procedure was then identical for all the subsequent HBSC surveys conducted in the Czech Republic.

Since 1996 the Czech HBSC study has been coordinated by the Prague Psychiatric Centre. In the 1998 survey nine questions were added to the HBSC questionnaire. These were questions on body weight and height, school climate, etc. Some questions were, on the other hand, excluded (e.g. place of residence, opinions on the future, pupils' expenditures). The questionnaire was thoroughly revised. Some items and scales became more specific but changes to the wording of former questions were minimal and the meaning of the recurring questions remained unchanged in most cases. The questionnaire comprised 69 questions. In this year, 67 schools participated in the data collection, which took place in grades 5 , 7 , and 9 (24), or their equivalents in junior high schools (6- or 8 -year secondary studies, similar to preparatory high schools in the USA or secondary grammar school in the UK). In total, 5,059 children were addressed to participate in the study, of whom eight refused to do so and another 504 children were absent from school at the time of the survey. The questionnaire was completed by 4,541 children, i.e. the response rate was $89.8 \%$.

In 2002, the study was still conducted by the Prague Psychiatric Centre. The questionnaire consisted of 71 questions, i.e. only two more than in 1998, but there was quite a substantial change in its composition. Questions on sexual behaviour and illicit drug use were added, as well as new measures of life satisfaction, selfrated health, moderate-to-vigorous physical activity, screen-based activities, family structure, or the onset of menstruation. Eighty schools out of the total number of 2,483 schools in the Czech Republic were randomly selected. The selection of particular classes to be surveyed was made using the same methodology as previously, in line with the international HBSC protocol (29). Of the 80 selected schools six refused to participate in the survey.
These schools were replaced by other schools located in their vicinity. Out of all the registered pupils $(5,844)$, only four students refused to participate in the survey. The number of absent students was $652(11.2 \%)$. The overall response rate was $88.8 \%$, i.e. questionnaires were obtained from 5,187 pupils.

In 2006, the study moved to the National Institute of Public Health in Prague. Ladislav Csémy was responsible for the study on behalf of the Czech Republic. The 2006 version of the questionnaire did not differ notably from the previous one. The changes that were made reflected societal development and concerned, for instance, the splitting of the question on time spent on a PC into chatting, surfing the Internet, and PC gaming. The questionnaire consisted of 79 questions in 2006. Of the 90 selected schools 86 were primary schools (in grades 5, 7, and 9) and junior high school (the second and fourth grades of the eight-year studies, corresponding to grades 7 and 9 in the primary schools). Out of the total number of 6,452 pupils, 5,711 participated in the survey (response rate $88.5 \%$ ).

In 2010, the coordinating role in the study was transferred from the National Institute of Public Health in Prague to the Faculty of Physical Culture of Palacký University Olomouc, and Michal Kalman replaced Ladislav Csémy as the principal investigator for the Czech HBSC. As in 2006, there were no major changes in the composition of the questionnaire. The total number of questions in the questionnaire was 75 and the new items focused e.g. on organized leisure-time activities or motives for physical activity. The data was collected in June 2010 in randomly selected schools. There were 6,092 pupils registered in the classes selected for the study and 5,306 of them were present at the time of the survey. Nobody declined to participate (response rate 87\%). Another 22 cases were excluded because of an excessive number of missing values throughout the questionnaire. After the data cleaning, the final sample comprised 4,425 respondents.

Five versions of the questionnaire were developed for the 2014 data collection - one for 11-year-olds and two for 13-year-olds and 15-year-olds. The version for the youngest age category was the shortest and comprised 75 questions. The versions for 13-year-olds were composed of more questions than the one for 11-year-olds and the versions for 15-year-olds even more, with 111 questions. The mandatory part of the questionnaire was identical for all the respondents (except for questions on sexual behaviour, cannabis, and substance use initiation, which were put only to 15 -year-olds) and covered the following research areas: socioeconomic status, health and well-being, eating habits, energy balance-related behaviours, substance use, family culture, peer culture, the school environment, injuries and violence, and sexual health. The questionnaires differed only with regard to optional or national items, with two versions for 13- and 15-year-olds. Two sets of questionnaires for the oldest age categories were used in order to include as many research areas as possible and to keep the length of the questionnaire age-appropriate. Thus, for instance, half of the 13- and 15-year-old respondents were asked about spirituality and social norms, while the other half answered questions on educational expectations and aspirations. The questionnaires were distributed in 243 schools across all regions of the Czech Republic (one school refused to participate) in order to ensure the data was representative for each region. There were 16,298 pupils registered in the selected classes and we obtained data from 14,539 of them; thus, the response rate was $89.2 \%$. 


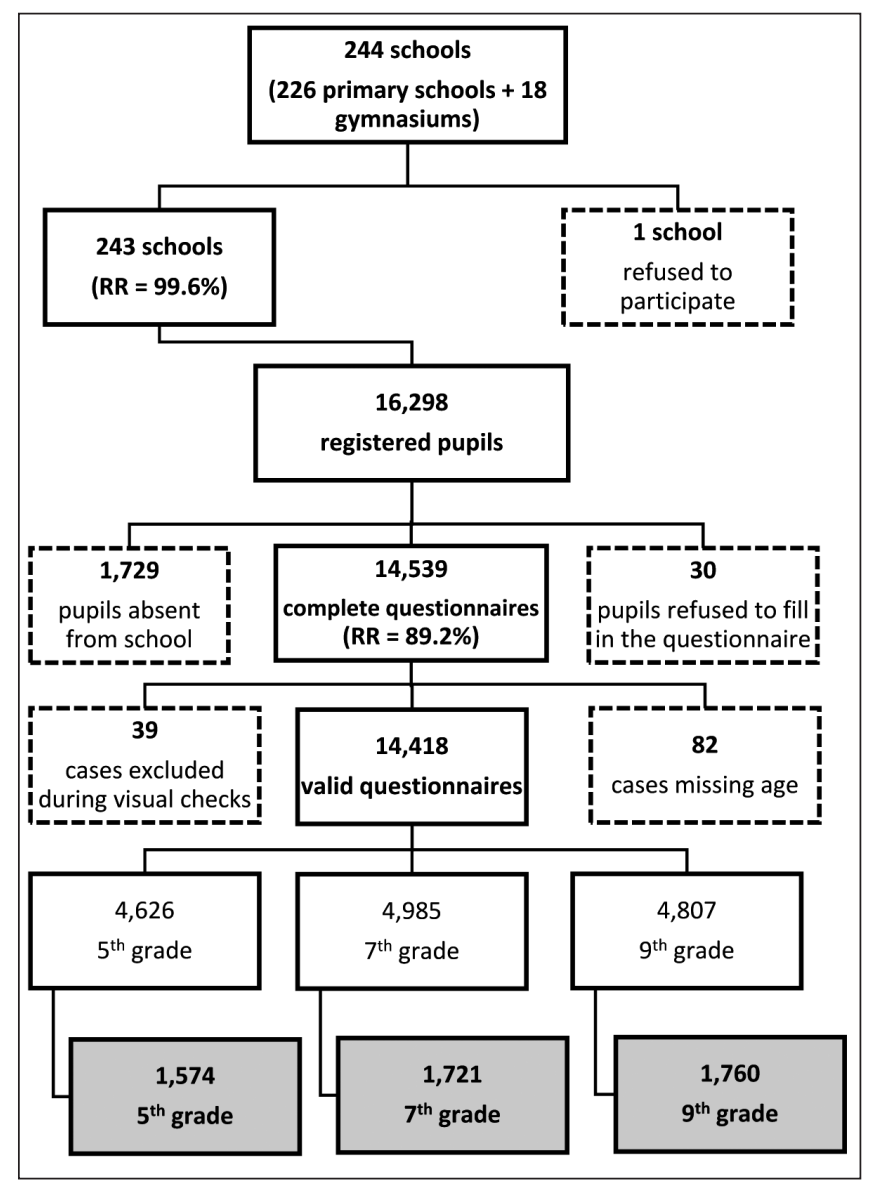

Fig. 1. Flowchart of the data collection and cleaning procedure in the Czech HBSC survey in 2013/2014.

$\mathrm{RR}$ - response rate

After visual checks of the questionnaire, the sample comprised 14,418 adolescents. For the cross-national comparison of the data 5,082 pupils were selected for inclusion in the international HBSC dataset (Fig. 1).

The strength of the HBSC study lies in its long-lasting history (over 30 years of the cross-national study and over 20 years in the Czech Republic), continual development, and option to compare the data at the international level, as well as analyzing the changes in various areas of adolescents' lives in relation to their health and well-being. The trend analyses use the design of a repeated cross-sectional survey. This allows the monitoring of trends in, for instance, physical activity, sedentary behaviour, and overweight/obesity (30-33), but also in other health indicators in Czech school-aged children (34-37). As such it provides important evidence for cross-national comparison and information for upcoming health or healthy lifestyle promotion programmes and feedback for the current ones. The HBSC, therefore, has the potential to promote healthy lifestyles among school-aged children in the Czech Republic and also abroad - in other Central or East European countries.

\section{Acknowledgements}

This work was supported by the research grant of the Czech Science Foundation Reg. No. 17-12579S.

\section{Conflict of Interests}

None declared

\section{REFERENCES}

1. Polit DF, Beck CT. Generalization in quantitative and qualitative research: myths and strategies. Int J Nurs Stud. 2010 Nov;47(11):1451-8.

2. Ilgen DR, Favero JL. Limits in generalization from psychological research to performance appraisal processes. Acad Manage Rev. 1985;10(2):31121.

3. Coolican H. Research methods and statistics in psychology. London: Hodder Education; 2009.

4. Laursen BP, Little TD, Card NA. Handbook of developmental research methods. New York: Guilford Press; 2012.

5. Shaffer D, Kipp K. Developmental psychology: childhood and adolescence. Belmont: Cengage Learning; 2013.

6. Thomas JR, Nelson JK, Silverman SJ. Research methods in physical activity. Champaign: Human Kinetics; 2011.

7. Delhez ÉJ, Deleersnijder É. Age and the time lag method. Cont Shelf Res. 2008;28(8):1057-67.

8. Hopkins WG. Quantitative research design. Sportscience. 2000;4(1):1-9.

9. McNeill P. Society now research methods. 2nd ed. New York, NY: Routledge; 1990.

10. Menard S. Longitudinal research. 2nd ed. Thousand Oaks: Sage; 2002.

11. Kerlinger FN. Foundation of behavioral research. Prague: Academia; 1972.

12. Lynn P. Methodology of longitudinal surveys. Chichester: John Wiley \& Sons; 2009.

13. Lechnerová $Z$. The characteristics and development of panel studies. Data a výzkum. 2009;3(1):31-51.

14. Grimes DA, Schulz KF. Cohort studies: marching towards outcomes. Lancet. 2002 Jan 26;359(9303):341-5.

15. Thadhani R, Tonelli M. Cohort studies: marching forward. Clin J Am Soc Nephrol. 2006 Sep;1(5):1117-23.

16. Trivellato U. Issues in the design and analysis of panel studies: A cursory review. Qual Quant. 1999;33(3):339-51.

17. Stanger C, Verhulst FC. Accelerated longitudinal designs. In: Verhulst FC, Koot HM, editors. The epidemiology of child and adolescent psychopathology. Oxford: Oxford University Press; 1995 p. 385-405.

18. Galbraith S. Accelerated longitudinal designs. In: Biometrics by the Blowholes; 2011 Dec 4-8; Kiama, New South Wales, Australia.

19. Bell RQ. Convergence: an accelerated longitudinal approach. Child Dev. 1953 Jun;24(2):145-52.

20. Mann CJ. Observational research methods. Research design II: cohort, cross sectional, and case-control studies. Emerg Med J. 2003 Jan;20(1):54-60.

21. Knuth AG, Hallal PC. Temporal trends in physical activity: a systematic review. J Phys Act Health. 2009 Sep;6(5):548-59.

22. Whitbourne SK, Waterman AS. Psychosocial development during the adult years: Age and cohort comparisons. Dev Psychol. 1979;15(4):373-8.

23. Dearth-Wesley T, Gordon-Larsen P, Adair LS, Zhang B, Popkin BM. Longitudinal, cross-cohort comparison of physical activity patterns in Chinese mothers and children. Int J Behav Nutr Phys Act. 2012 Apr 3;9:39. doi: 10.1186/1479-5868-9-39.

24. Currie C, Gabhainn SN, Godeau E; International HBSC Network Coordinating Committee. The Health Behaviour in School-aged Children: WHO Collaborative Cross-National (HBSC) study: origins, concept, history and development 1982-2008. Int J Public Health. 2009 Sep;54 Suppl 2:131-9.

25. Inchley J, Currie D, Young T, Samdal O, Torsheim T, Augustson L, et al. editors. Growing up unequal: gender and socioeconomic differences in young people's health and well-being. Health Behaviour in School-aged Children (HBSC) study: international report from the 2013/2014 survey. Copenhagen: WHO Regional Office for Europe; 2016.

26. Currie C, Inchley J, Molcho M, Lenzi M, Veselska Z, Wild F, editors. Health Behaviour in School-aged Children (HBSC) study protocol: background, methodology and mandatory items for the 2013/2014 survey. St. Andrews: Children and Adolescent Health Research Unit; 2014.

27. Roberts C, Freeman J, Samdal O, Schnohr CW, de Looze ME, Gabhainn $\mathrm{SN}$, et al.; International HBSC Study Group. The Health Behaviour in School-aged Children (HBSC) study: methodological developments and current tensions. Int J Public Health. 2009 Sep;54 Suppl 2:140-50.

28. King A, Wold B, Tudor-Smith C, Harel Y. The health of youth. A crossnational survey. WHO Reg Publ Eur Ser. 1996;69:1-222.

29. Currie C, Samdal O, Boyce W, Smith R, editors. Health Behaviour in School-Aged Children: a WHO cross-national study (HBSC): research protocol for the 2001/2002 survey. Edinburgh: CAHRU; 2001. 
30. Sigmundová D, Sigmund E, Hamrik Z, Kalman M. Trends of overweight and obesity, physical activity and sedentary behaviour in Czech schoolchildren: HBSC study. Eur J Public Health. 2014 Apr;24(2):210-5.

31. Sigmund E, Sigmundová D, Badura P, Kalman M, Hamrik Z, Pavelka J Temporal trends in overweight and obesity, physical activity and screen time among Czech adolescents from 2002 to 2014: A National Health Behaviour in School-Aged Children Study. Int J Environ Res Public Health. 2015 Sep 18;12(9):11848-68.

32. Bucksch J, Sigmundova D, Hamrik Z, Troped PJ, Melkevik O, Ahluwalia $\mathrm{N}$, et al. International trends in adolescent screen-time behaviors from 2002 to 2010. J Adolesc Health. 2016 Apr;58(4):417-25.

33. Kalman M, Hamrik Z, Sigmund E, Sigmundová D, Salonna F; Czech National HBSC team. Physical activity of Czech adolescents: Findings from the HBSC 2010 study. Acta Gymnica. 2015;45(1):3-11.

34. Voráčová J, Sigmund E, Sigmundová D, Kalman M. Changes in eating behaviours among Czech children and adolescents from 2002 to 2014 (HBSC Study). Int J Environ Res Public Health. 2015 Dec $15 ; 12(12): 15888-99$.
35. Vokacova J, Badura P, Pavelka J, Kalman M, Hanus R. Brief report: changes in parent-adolescent joint activities between 2002 and 2014 in the Czech Republic, Health Behaviour in School-aged Children (HBSC) study. J Adolesc. 2016 Aug;51:1-5.

36. Boniel-Nissim M, Lenzi M, Zsiros E, de Matos MG, Gommans R, HarelFisch Y, et al. International trends in electronic media communication among 11- to 15-year-olds in 30 countries from 2002 to 2010: association with ease of communication with friends of the opposite sex. Eur J Public Health. 2015 Apr;25 Suppl 2:41-5.

37. Pickett W, Molcho M, Elgar FJ, Brooks F, de Looze M, Rathmann K, et al. Trends and socioeconomic correlates of adolescent physical fighting in 30 countries. Pediatrics. 2013 Jan;131(1):e18-26.

Received January 17, 2017 Accepted in revised form June 2, 2017 